\title{
Yönetim Bilişim Sisteminin Bir Örneği Olarak Türkiye'de Elektronik Seçim Sistemi
}

\section{Electronic Selection System in Turkey as an Example of Management Information System}

\begin{abstract}
Veysel EROL ${ }^{1 *}$
Geliş / Received: 02/11/2021

Revize / Revised: 12/11/2021

Kabul / Accepted: 02/12/2021

ÖZ

Son yıllarda teknolojinin hızlı bir ivmeyle gelişmesiyle birlikte, elektronik seçim sistemleri, klasik kâğıt oy pusulaları ile yapılan seçimlerin yerini almaktadır. Elektronik seçim sistemi, seçmenlerin kullandıkları oyların elektronik makinelerle toplanıp değerlendirilmesini sağlayan bir sistemdir. Elektronik seçim sistemi ile birlikte, oy verme işleminin daha hızlı ve daha kolay bir şekilde yürütülmesi sağlanmakta ve bu sistemle, klasik kâğıt oy pusulalarında yaşanan sorunların önüne geçilmesi amaçlanmaktadır. Elektronik seçim sisteminin önemli avantajları bulunmakla birlikte, bu sistemde önemli sorunlar da ortaya çıkabilmektedir. Elektronik seçim sistemi uygulaması, dünyanın birçok ülkesinde başarılı bir şekilde uygulanmakta ve yakın gelecekte de bu uygulamayı kullanacak ülke sayısının artması beklenmektedir. Birçok ülkede olduğu gibi, Türkiye'de de elektronik seçim sistemi ile ilgili önemli çalışmalar yapılmakta ve bu çalışmaların sayısı gün geçtikçe artmaktadır. Bu çalışmada, öncelikle yönetim bilişim sisteminin önemli bir örneği olan elektronik seçim sistemi uygulamasının kavramsal çerçevesine değinilmekte ve bu uygulamayı kullanan ülkelerden örnekler verilmektedir. Çalışmada, ayrıca, elektronik seçim sisteminin Türkiye'de uygulanması halinde nasıl bir yol izlenmesi gerektiği ortaya konulmakta ve karşılaşılacak sorunların çözümü konusunda öneriler getirilmektedir.

Anahtar Kelimeler: Yönetim Bilişim Sistemi, Klasik Seçim Sistemi, Elektronik Seçim Sistemi, Seçmen, Güvenlik
\end{abstract}

\begin{abstract}
In recent years with the rapid development of technology electronic election systems are replacing traditional paper ballots. The electronic election system is a system that enables the votes of the voters to be collected and evaluated by electronic machines. With the electronic election system, the voting process is carried out faster and easier, and with this system, it is aimed to prevent the problems experienced in traditional paper ballot papers. Although the electronic election system has important advantages, important problems may arise in this system. Electronic election system application is successfully implemented in many countries of the world and the number of countries that will use this application is expected to increase in the near future. As in many countries, important studies are carried out on the electronic election system in Turkey and the number of these studies is increasing day by day. In this study, first of all, the conceptual framework of the electronic election system application, which is an important example of the management information system, is mentioned and examples from the countries using this application are given. In the study, it is also revealed how the electronic election system should be implemented in Turkey, and suggestions are made for the solution of the problems to be encountered.
\end{abstract}

Keywords: Management Information System, Classical Election System, Electronic Selection System, Voter, Security.

\footnotetext{
1* Sorumlu Yazar, Dr., Kütahya Dumlupınar Üniversitesi, Lisansüstü Eğitim Enstitüsü, Kamu Yönetimi Anabilim Dalı, veysel.erol43@gmail.com, (https://orcid.org/0000-0002-6949-768X)
} 


\section{GíRiş}

Demokrasinin vazgeçilmez temel unsurlarından birisi olan seçimler, bireylerin geleceklerini belirlemede başvurdukları en etkili siyasi katılım aracıdır. Seçimler, ülkeler için hayati bir öneme sahip olmasından dolayı, büyük ilgi görmektedir. Seçim sistemleri ise seçim sürecinde uygulanan yöntem ve teknikleri kapsamaktadır. Seçim sistemleri belirlenirken "temsilde adalet" ve "yönetimde istikrar" ilkelerine dikkat edilmektedir. Birçok ülkede uzun yıllardır klasik kâğıt oy pusulası seçim sistemi uygulanmaktadır. Ancak, bilişim sistemlerinin gelişmesiyle birlikte, klasik seçim sistemi yerini elektronik seçim sistemine bırakmaktadır.

Elektronik seçim sistemi, yönetim bilişim sisteminin önemli bir örneğini oluşturmakta ve bu sistemle birlikte, seçimlerin daha kolay ve daha hızlı bir şekilde yapılması sağlanmaktadır. Elektronik seçim sistemi hem zaman açısından hem de seçim maliyetlerinin azaltılması açısından önemli kazançlar sağlamaktadır. Ancak, her sistemde olduğu gibi, elektronik seçim sisteminde de başta özel güvenlik sorunları olmak üzere çeşitli sorunlar yaşanabilmektedir. Dolayısıyla bu seçim sistemi bir yandan desteklenirken, diğer yandan da bazı yönleriyle eleştirilerek büyük tartışmalara yol açabilmektedir.

Elektronik seçim sistemi ile ilgili önemli tartışmalar olmasına rağmen, bu sistem başta Brezilya, Hindistan ve Venezuela olmak üzere birçok ülkede başarılı bir şekilde uygulanmaktadır. Özellikle halkın bilgisayar okuryazarlığının düşük olduğu ülkelerden biri olan Hindistan’da, bu seçim sisteminin uygulanması, diğer ülkeler içinde örnek teşkil etmektedir. Birçok ülkede olduğu gibi, Türkiye'de de elektronik seçim sistemine yönelik son yıllarda önemli çalışmalar yapılmaktadır.

Türkiye'de elektronik seçim sistemlerine yönelik ilk çalışma Seçim Bilişim Sistemi (SEÇSİS) projesidir. SEÇSİS projesi, 22 Temmuz 2007 seçimlerinden beri uygulanmakta, ancak, bu projenin geçmişi 1986 yılına kadar uzanmaktadır. Bu durum, Türkiye'nin de diğer ülkelerde olduğu gibi, teknolojiden uzak olmadığını göstermektedir. Seçim ile ilgili işlemlerin hızlı yürütülmesini sağlayan ve siyasi partilerin de erişimine açık olan SEÇSİS projesi, elektronik seçim sistemine geçiş aşamasının ön çalışması olarak görülmektedir.

Türkiye'de uygulanabilecek elektronik seçim modeli ise, Hava Elektronik Sanayi (HAVELSAN) tarafından tasarlanan elektronik seçim sandığı (e-sandık) gösterilebilir. İlk defa Türkiye Bilişim Derneği’nin seçimlerinde kullanılan elektronik seçim sandığı büyük beğeni toplamıştır. Elektronik seçim sandığı uygulaması, birçok eleştiriye sebep olsa da bu uygulamanın ilerleyen yıllarda yalnızca yerel seçimlerde değil, genel seçimlerde de kullanılması beklenmektedir.

$\mathrm{Bu}$ çalışmanın temel amacı, Türkiye'de elektronik seçim sisteminin uygulanabilirliği konusunda önerilerde bulunmaktır. Çalışmada, öncelikle yönetim bilişim sisteminin kavramsal çerçevesine değinilmektedir. Daha sonra elektronik seçim sisteminin kavramsal çerçevesi ele alınmakta ve bu seçim sistemini uygulayan ülkelerden örnekler verilmektedir. Sonrasında ise Türkiye'de elektronik seçim sisteminin uygulanabilirliği ele alınmakta ve karşılaşılacak sorunlara çözüm önerileri getirilmektedir.

\section{YÖNETIM BILLIŞIM SISTEMI}

20. yüzyılın ikinci yarısından itibaren ve özellikle küreselleşme ve bilgi toplumuna geçiş süreciyle birlikte, başta bilişim sistemleri olmak üzere birçok alanda önemli gelişmeler yaşanmış ve bu gelişmeler 21 . yüzyılda da halen artarak devam etmektedir. Bilişism sistemlerinin gelişmesiyle birlikte, bilgi işlem sürecinin hızı artmaya başlamış ve bu durum her geçen gün daha da önemli bir noktaya gelmektedir.

Bilişim sistemleri, genel olarak, "veri, bilgi ya da işlenmiş bilginin rakam, sayı, yazı, resim, ses ve görüntü biçiminde elde edilmesini, depolanmasını, düzenlenmesini, geri çağırılmasını, istenilen formata dönüştürülmesini, bir yerden başka bir yere iletilmesini sağlayan, teknoloji, yazılım ve insan kaynaklarının bir araya gelmesiyle oluşan bir bütün" (Güleş ve Özata, 2005: 36) şeklinde tanımlanmaktadır.

Günümüzde, etkin ve hızlı bilgi akışını sağlayan bilişim sistemlerinin hem kamu yönetiminde hem de özel sektörde kullanılması zorunluluk haline gelmiştir. Ancak, bilişim sistemlerinin etkin bir şekilde kullanılması 
için organizasyon, teknoloji ve yönetime de hâkim olmak gerekmektedir. Aşağıdaki şekilde de görüldüğü üzere, organizasyon, teknoloji ve yönetim, bilişim sistemlerinin temel öğelerini oluşturmaktadır.

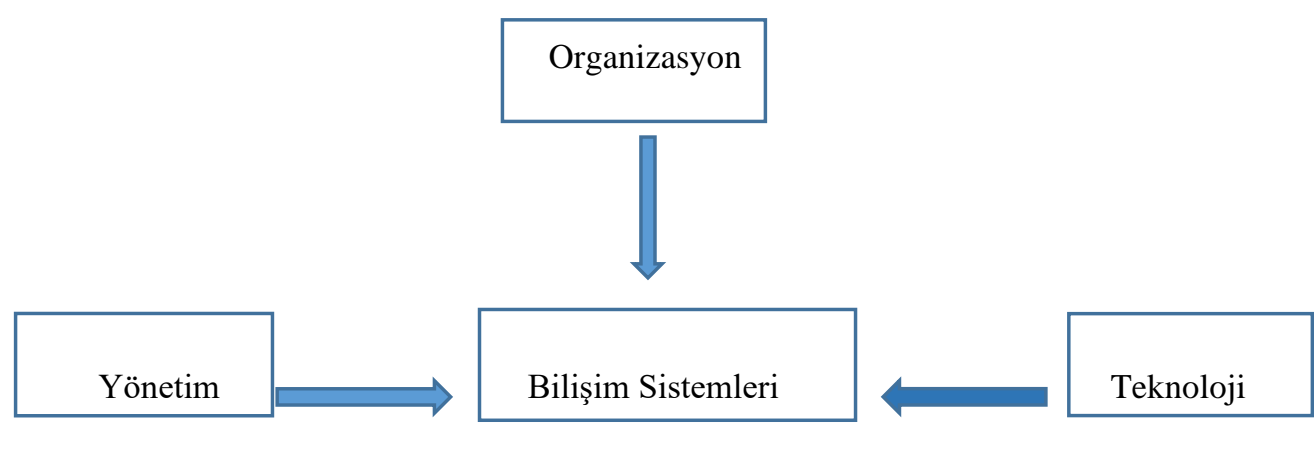

Şekil 1. Bilişim sistemlerinin temel öğeleri

İşletmelerin yönetsel birimlerinde kullanılan yönetim bilişim sistemleri ise yönetimlerin bilgi işlem sürecini daha kolay ve hızlı bir duruma getirmektedir. Eklektik bir yapıya sahip olan yönetim bilişim sistemleri, yönetimi, bilgiyi, teknolojiyi ve sistemi bir araya getirmektedir. Dolayısıyla yönetim bilişim sistemleri, disiplinler arası bir inceleme alanı olarak karşımıza çıkmaktadır.

İlk kez 1960’lı yıllardan sonra kullanılmaya başlanan yönetim bilişim sistemi kavramının, herkes tarafından kabul edilen evrensel bir tanımı bulunmamaktadır. Dolayısıyla yönetim bilişim sistemleri hakkında farklı görüşler bulunmakta ve genellikle bu konuda ayrı tanımlar yapılabilmektedir.

Yönetim bilişim sistemi, genel olarak, işletme planlarının ve yönetim işlevlerinin etkinliğini artırmak amacıyla insan ve bilgisayar tabanlı kaynakların toplanması, saklanması, değerlendirilmesi, iletişimi ve kullanımı olarak ifade edilmektedir. Yönetim bilişim sistemleri, yönetime düzenli olarak bilgi sağlayan sistemlerdir ve organizasyonlarda bilgi sistemi geliş̧irilmesini ve verimli kullanılmasını ifade etmektedir. Yönetim bilişim sistemi içinde yönetim kelimesi bulunmasına rağmen yalnızca yönetimi değil, işletmenin bütün kademelerini içermektedir (Yozgat, 1998: 155).

Yönetim bilişim sistemleri, idarecilere karar verebilmeleri için bilgi sağlayan, bilgisayar kullanan bilgi ağlarıdır. Bu sistemin temel amacı, doğru kişiye, doğru zamanda kullanılabilir bilgiyi ulaştırmaktır. Sistem, bir organizasyonda işleri, yönetimi, analiz ve karar işlevlerini desteklemek amacıyla bilgi sağlayan bilgisayar ve kullanıcılarından oluşan, bütünleşik bir sistemdir. Yönetim bilişim sistemlerinin temel fonksiyonu; yönetimin hedeflerine en etkin bir şekilde ulaşmasını sağlayacak, insan, makine, sermaye, hammadde ve malzeme unsurları arasındaki karşılıklı ilişkileri en uygun şekilde düzenleyecek olan karar organlarına doğru zamanlı ve anlamlı bilgi ulaştırmaktır (Yozgat, 1998: 155-156). Dolayısıyla yönetim bilişim sistemleri, işletme içindeki organlara doğru ve anlamlı bilgi ulaştırarak verimliliği ve etkinliği artırmayı amaçlamaktadır.

Yönetim bilişim sistemlerine ait temel özellikler şu şekilde sıralanabilir (Özgen ve Yalçın, 1992: 251252; Gümüştekin, 2004:130-131):

- Yönetim Bilişim Sistemi, Bütünleşik Bir Sistemdir. Yönetim bilişim sistemindeki bütün alt sistemlerin çalışmalarının birbirleriyle ilişkili olması durumu alt sistemlerin bütünleşmiş olduğunu göstermektedir. $\mathrm{Bu}$ bütünleşme alt sistemler arasındaki iletişim ile sağlanmaktadır. Yönetim bilişim sisteminin bütünleşik bir sistem olmasından dolayı, yönetim için gerekli olan bilgiler de ortak bir veri tabanından sağlanmaktadır.

- Yönetim Bilişim Sistemi, Verimliliği Artıran Bir Sistemdir. Yönetim bilişim sistemi, çeşitli yollarla verimliliği artırabilmektedir. Doküman hazırlama gibi olağan olan işlerin daha hızlı ve daha iyi işlemesine yardımcı olmaktadır. Yönetim bilişim sistemi, örgüt içi sorunlar ve dış tehditler konusunda önceden uyarı yapmaktadır. Ayrıca, işletme için önemli sayılabilecek firsatlara da dikkat çekmektedir. 
- Yönetim Bilişim Sistemi, Bilgisayar Temeline Dayanan İnsan-Makine Sistemidir. Bilgisayar desteği olmadan da yönetim bilişim sistemi oluşturulabilir. Ancak, yönetim bilişim sisteminin etkin bir şekilde işleyebilmesi için bilgisayarın kullanılması zorunluluktur. Bilgisayar, yönetim bilişim sistemine gerekli olan bilgilerin, doğru, tutarlı ve hızlı bir şekilde işlemesini sağlamaktadır.

- Yönetim Bilişim Sistemi, Bilgi Desteğini Sağlayan Bir Sistemdir. Yönetim bilişim sisteminde, günlük işlemlere yönelik birçok bilgi işlenmekte ve bu bilgiler hayati önem taşıyan bilgi yığınına girdi sağlamaktadır. Böylece idareciler için veriler ya da bilgiler, daha yararlanabilir ve düzenli şekilde saklanmış olmaktadır.

- Yönetim Bilişim Sistemi, Karar Sürecine Bir Destektir. Yönetim bilişim sistemi için gerekli görülen ve bir kararı oluşturabilecek şekilde toplanan bilgilerin, işlenmesi, incelenmesi ve sunulması gerekmektedir. Bunun içinde, çeşitli karar durumlarına ulaşan sayısal olan ya da olmayan örneklerden faydalanılarak, karar almaya destek olacak karar örnekleri oluşturulmaktadır.

- Yönetim Bilişim Sistemi, Koordine Edilmiş Bir Sistemdir.Bir işletmede, yönetim bilişim sisteminin parçaları tek bir merkezden yönetilmemektedir. Bütün bölümlerin yönetim bilişim parçaları üzerinde kullanma yetkisi bulunmaktadır. Ancak, yönetim bilişim sistemi, ofis otomasyonu, bilgi işlem, haber alma ve karar destek sistemlerinin kurulup geliştirilmesini sağlamak içi tek bir merkezden koordine edilmektedir. Bu koordinasyon sistemi, bilgi işlem yöneticisi ya da ayrı bir komite tarafından yürütülmektedir.

Yönetim bilişim sisteminin birçok örneği bulunmakla birlikte, bu örnekler arasında en çok dikkat çekenlerin başında ise elektronik seçim sistemi gelmektedir. Elektronik seçim sistemi, birçok ülkede uygulanmakta ve bu sistem, seçimlerin daha hızlı sonuçlanmasını sağlamaktadır. Çalışmanın bundan sonraki bölümünde, yönetim bilişim sisteminin bir örneği olan elektronik seçim sisteminin kavramsal çerçevesi, bu seçim sistemini uygulayan ülkelerden örnekler ve bu sistemin Türkiye'de uygulanabilirliği üzerinde durulacaktır.

\section{ELEKTRONIK SEÇIM SISTEMI}

Bilgisayarların ve elektronik araçların hayatımızın her alanında kullanıldı̆̆ bu çağda bireyler tüm işlemlerini elektronik ortamda yapabiliyorken, bu süreçte elektronik demokrasi (e-demokrasi) kavramının da doğal bir ihtiyaç olduğu ortadadır. Günümüzde e-demokrasi yolunda e-referandum, e-seçim, e-oylama, e-sandık, e-noter, e-dilekçe gibi birçok konudan gelecekte çok daha fazla söz edileceği düşünülmektedir. Ancak, vatandaşların yani kullanıcıların kişisel bilgilerinin gizliliği açısından, sistemin aktif ve pasif olmak üzere her türlü saldırılara karşı daha açık olmasından ve sonuçların bütün vatandaşları doğrudan ilgilendirmesi açısından, e-seçim (elektronik seçim), e-demokrasi konuları arasında en çok önem gösterilmesi gereken konuların başında gelmektedir (Çetinkaya ve Çetinkaya, 2006: 123).

E-demokrasi yolunda yapılan çalışmalarla birlikte tartışılmaya başlanan elektronik seçim sistemi, kısaca, vatandaşların siyasi bir konu hakkında elektronik araçlar ile oy kullanması ve seçim sonuçlarının bu sistemden yayınlanması (Buchsbaum, 2004: 32) şeklinde tanımlanabilir. Bu seçim sistemi ile birlikte, seçim dönemlerinde daha hızlı ve daha kolay bir şekilde oy kullanılabilecektir.

Elektronik seçim sistemlerinin şaşırtıcı derecede uzun bir geçmişi vardır. ABD’de, mekanik kollu oylama makineleri ilk kez 1892 seçimlerinde kullanıldı ve 1990'lı yıllara kadar ABD seçimlerinde bu makineler sıkça kullanılmaktayd1. Elektronik teknolojiler ise 1960'larda yumruk kartlı makinelerle ortaya çıkmaya başladı. Sonraki yıllarda, DRE (Doğrudan Kayıt Sistemi) oy verme makineleri, oy pusulası tarama makineleri ve internet oyları gibi teknolojiler ortaya çıkmaya başladı. Bu teknolojileri benimseyen ülkelerin başında ABD gelmekteydi. 1990'dan sonra ise dünyada birçok ülkede bu teknolojiler benimsendi. Son yapılan araştırmalar, dünya çapında 31 ülkenin seçimlerde uzaktan olmayan elektronik oylama makinelerini kullandığını göstermiştir. Bu ülkelerden bazıları elektronik oylama makineleri denemiş ve kullanmaya devam etmeyeceklerini açıklamışlardır. Elektronik oylama makineleri 20 ülkede kullanılmakta ve altı ülkede bu teknolojiyi denemek için hala çalışmaktadır. Elektronik seçim sistemlerinde, küresel olarak farklı bölgelerde farklı eğilimler görülmektedir. Avrupa ve Kuzey Amerika, elektronik oylama makinelerinin kullanımından uzaklaşırken, Güney Amerika ve Asya'da elektronik oy 
teknolojilerinin kullanılması konusundaki ilgi artmaktadır (NDI, 2013). Türkiye'de ise elektronik seçim sistemine yönelik çalışmalar son yıllarda hız kazanmaya başlamıştır.

Bilgi ve iletişim teknolojisinin geliştiği bu dönemde, elektronik seçim sistemleri de gün geçtikçe daha çok ön plana çıkmaktadır. Elektronik seçim sistemi için gerekli olan kriterlere, bu sistemin avantajlarına ve bu sistemden yaşanan sorunlara değinmeden önce, Türkiye'de uygulanan klasik seçim sistemi üzerinde kısaca durmak gerekmektedir. Böylece elektronik seçim sistemi ile klasik seçim sistemi arasındaki fark görülmüş olacaktır.

Demokrasinin kalbi olarak ifade edilen seçimler, hemen her siyasal sistemde en önemli konular arasında yer almaktadır. Birçok ülkede olduğu gibi, Türkiye'de de seçimler hayati önem taşımaktadır. Türk siyasal hayatında ilk seçim ise çok partili hayata geçilmesinin ardından 1946 yılında yapılmıştır. Türkiye'de 1946-1960 yılları arasında çoğunluk seçim sistemi uygulanırken, 1960 yılından sonra ise çoğunluk seçim sistemi terk edilerek nispi temsil sistemine geçilmiş̧ir. Günümüzde uygulanan mevcut klasik seçim sistemi de nispi temsil sisteminin bir çeşidi olan d'Hondt usulüdür.

Türkiye'de uygulanan klasik seçim sistemi, Yüksek Seçim Kurulu tarafından mevzuata uygun şekilde gerçekleştirilmektedir. Genel, yerel ya da referandum gibi seçimlerde uygulanan seçim sistemini kısaca özetlemek gerekirse; öncelikle seçim günü kararlaştırmakta, ardından seçmen yoklamaları, aday belirleme işlemleri, seçim gününde görev alacak sandık görevlileri, sandık ve oy pusulaları belirlendikten sonra seçim işlemi başlatılmaktadır. Sandık görevlileri seçime yönelik daha önce almış oldukları eğitimleri tamamladıktan sonra sandığın başına geçmekte ve vatandaşların seçme işlemini güvenilir bir şekilde yapmalarına yardımcı olmaktadır. Vatandaşlar kendilerine gelen seçmen kâğıdı ile ya da kimlikleriyle birlikte oy kullanacağı sandığa gitmekte (Erzurumlu ve Koloğlu, 2017: 2) ve kapalı oy verme yerinde oy verme işlemeni gerçekleştirmektedir. Sandık görevlisi, oyunu kullanan seçmene kimliğini iade ederken aynı zamanda seçim listesinde adının bulunduğu yerde imzasını da attırarak oy kullanma işlemini tamamlamaktadır. İmza atamayanlar ise sol elinin başparmağının izi alınmasıyla oylarını kullanabilmektedir (Aydın, 2015: 333). Seçmen listesinde yer alanların tamamının oylarını kullanması ya da oy verme süresinin dolmasından sonra gerekli önlemler alınarak oyların sayımı ve dökümü açık şekilde gerçekleştirilmektedir. Oyların sayılıp ilan edilmesinden sonra da seçim sonucu açıklanmaktadır.

Türkiye'de yıllardır klasik seçim sistemi uygulanılmasına rağmen bazı sorunlarında yaşandığını belirtmek gerekmektedir. Klasik seçim sisteminde, fazla oy pusulasının çıkması, ciddi sayıda geçersiz oylardan bahsedilmesi, ölmüş vatandaşların yerine oyların kullanılması ve oy sayımı için saatlerce beklenilmesi gibi sorunlar ilk akla gelenlerdir. Ancak, bu sistemde yaşanan sorunlara rağmen, seçmenlerin ve kullandıkları oyların gizliliğinin sağlanması açısından ve sayımlarında bilindiği ve inanıldığ kadar doğru yapılıyor olması açısından, klasik seçim sisteminin güvenilir olduğu söylenebilir (Çetinkaya ve Çetinkaya, 2006: 126). Dolayısıyla uygulanabilecek bir elektronik seçim sisteminin hem en az klasik seçim sistemi kadar güven vermesi hem de birtakım kolaylıklar sağlaması gerekmektedir.

\section{A. Elektronik Seçim Sistemi İçin Kriterler}

Elektronik seçim sistemine geçmedeki en önemli etkenlerin başında, kâğıt oy pusulalarında yaşanan sorunlar gelmektedir. Yeni seçim sistemi ile birlikte, klasik seçim sisteminde yaşanan sorunların önüne geçilmesi amaçlanmaktadır. Bilindiği üzere, oy sayımı sırasında seçmenlerin bilmeden yaptıkları hatalar, geçersiz sayılan oy pusulaları, aynı seçmenin birden fazla oy kullanması ya da başkası adına oy kullanması gibi sorunlar yaşanabilmektedir. Bunun yanı sıra, vatandaşların yapılan hatalara itirazları, yapılan hataların isteyerek yapıldığına dair şikâyetleri, seçim sürecini olumsuz etkilemektedir. Bunlar göz önüne alındığında, yeterli güvenlik önlemeleri alınarak uygulanabilecek olan bir elektronik seçim sistemi, seçim sonuçlarına klasik seçim sistemine oranla çok daha hızlı şekilde ulaşmamıza yardımcı olabilecektir (Erzurumlu ve Koloğlu, 2017: 3). Ancak, elektronik seçim sisteminin güvenli bir şekilde uygulanabilmesi için bu sistemin, belli kriterlere göre tasarlanması gerekmektedir. 


\section{BŞEÜ Sosyal Bilimler Dergisi}

$6(2), 427-440,2021$
BSEU Journal of Social Sciences

https://doi.org/10.33905/bseusbed.1018151

Elektronik seçim sistemlerinde gizli ve güvenli oy kullanılması için uyulması gereken kriterler şu şekilde gösterilebilir (Internet PolicyInstitute, 2001: 11):

- Uygunluk ve Kimlik Doğrulama: Yalnızca oy hakkı olan seçmenler oy kullanabilmelidir.

- Teklik: Hiçbir seçmenin birden fazla oy kullanmaması gerekmektedir.

- Doğruluk: Kullanılan oylar doğru bir şekilde kaydetmelidir.

- Bütünlük: Oylar tespit edilmeden değiş̧tirilmemeli, kopyalanmamalı ya da silinmemelidir.

- Doğrulanabilirlik ve Denetlenebilirlik: Kullanılan tüm oyların doğru bir şekilde hesaplandığını doğrulamak mümkün olmalı ve güvenilir bir şekilde gerçeği ispat edilebilir seçim kayıtları tutulmalıdır.

- Güvenilirlik: Seçim sırasında, oy verme makinelerinin arızalanması ve internet iletişiminin tamamen kesilmesi dâhil olmak üzere çok sayıda arıza olması durumunda bile, herhangi bir oy kaybı olmadan sistemin sağlam bir şekilde çalı̧̧ması gerekmektedir.

- Gizlilik ve Zorlamama: Seçmenin kullanmış olduğu oyu kimse öğrenmemeli ve seçmenlerin baskı altında olmamaları için nasıl oy kullandıkları ispat edilmemelidir.

- Esneklik: Çeşitli oy seçenekleri formlarının (örneğin adayların isimlerinin yazılması, anket soruları, çoklu dil) kullanılmasına izin verilmeli, çeşitli standart platformlarla ve teknolojiler ile uyumlu olmalı ve engellilere erişim olanağı sağlanmalıdır.

- Kolaylı: Seçmenler, oylarını en az sayıda ekipmanla ya da hızlı bir şekilde kullanabilmelidir.

- Onaylanabilirlik: Seçim sistemleri, seçim görevlileri tarafından gerekli kriterleri karşıladıklarına dair güven duymaları için test edilebilir olmalıdır. olmalıdır.

- Şeffaflı: Seçmenler, oy verme süreci hakkında genel bir bilgiye sahip olmalı ve oylama süreci de şeffaf

- Maliyet etkinliği: Seçim sistemlerinin fiyatı uygun ve verimli olmalıdır.

Elektronik seçim sisteminin güvenli bir şekilde uygulanabilmesi için söz konusu kriterlerin neredeyse tamamının karşılanması gerekmektedir. Yeni seçim sisteminde, bu kriterlerin sağlanması ve güvenli bir denetim yapılabilmesi halinde hem zaman hem de maddi açıdan önemli kazançlar elde edilebilecektir.

\section{B. Elektronik Seçim Sisteminin Avantajları}

Seçimlerde kullanılan her oyun sonuca önemli etkisi olabilmektedir. Türkiye'deki son seçimde de (24 Haziran 2018) 1 milyonun üzerinde geçersiz oy çıktığı düşünüldüğünde, uygulanabilecek güvenli bir elektronik seçim sisteminin önemi de ortaya çıkmaktadır. Elektronik seçim sisteminin başlıca avantajları şu şekilde suralanabilir:

- Elektronik seçim sisteminin doğru ve güvenilir bir şekilde tasarlanması halinde, klasik seçim sistemlerinde yaşanan "geçersiz oy" kullanımının önüne geçilebilir.

- Klasik seçim sisteminde oylar elle sayılmasından dolayı eksik oylar çıkabilmektedir. Elektronik seçim sisteminde ise oylar otomatik olarak sayılmasından dolayı, elle sayım sırasında ortaya çıkan hatalar önlenebilir.

- Elektronik seçim sisteminde kullanılan oylar klasik seçim sistemine göre çok daha hızlı bir şekilde açıklanabilir (Türkiye'de 30 Mart 2014 yerel seçimlerinde bunun önemi bir kez daha görülmüş oldu).

- Seçim güvenliği sağlanabilir. Oylama elektronik ortamda yapılacağ için tüm oylar güvenli bir yerde saklanabilir ve bu güvenliğin sağlanması halinde oyların kaybolması ya da yok edilmesi söz konusu olmayacaktır. 
- Seçim maliyetleri önemli derecede azaltılabilir.

- Seçim gizliliği sağlanabilir.

- Engelli seçmenlerin daha kolay oy vermesi sağlanabilir (örneğin, oy pusulasına yüksek sesle okuyan yazılım eklenerek görme engelli olanlar için kolaylıklar sağlanabilir).

- Elektronik seçim sistemi tamamen yeşil bir uygulama olduğu için hem kağıt hem de mürekkep israfının önüne geçilebilir.

- Elektronik seçim sistemi tamamen görsel olduğu için de okuryazar olmayanlar bu sistemi kolay bir şekilde kullanabilir.

- Elektronik seçim sisteminin güvenli bir şekilde uygulanması halinde, seçimlerde öne sürülen "yolsuzluk" iddialarının da önüne geçilebilir.

\section{Elektronik Seçim Sistemlerinde Yaşanan Sorunlar}

Elektronik seçim sisteminin önemli avantajları bulunmakla birlikte, bu sistemde önemli sorunlar da yaşanabilmektedir. Yalnız elektronik seçim sistemlerinde değil, tüm elektronik oylama sistemlerinde hatalar meydana gelebilmektedir (Barlow, 2003: 6). Nitekim herkesin ortak noktada birleştiği güvenilir standart bir elektronik seçim sistemi bulunmamaktadır. Dolayısıyla elektronik seçim sisteminde sorunlar ortaya çıkabilmektedir.

Elektronik seçim sistemlerinde doğru ve güvenilir sonuç elde edebilmek için aşılması gereken üç temel sorun bulunmaktadır. Bu üç temel sorun; teknik sorunlar, hatalı kullanım ve sahtekârlık olarak sıralanabilir. Teknik Sorunlar: Elektronik seçim sistemi oyları hatalı ya da eksik kaydedebilir. Bu sistemde oluşabilecek geçici ya da kalıcı bir sorun karşısında oyların bir kısmı ya da tamamı kaybolabilir. Bu sorunun fark edilmesi halinde en iyi olasılıkla oylama tekrar yapılabilir. Hatalı Kullanım: Sandık görevlilerinin ve seçmenlerin elektronik oylamaya yönelik yeterli şekilde eğitilmemeleri durumunda oyların kaydedilmesiyle ilgili hatalar oluşabilir. Bunun yanı sıra, oylamadan önce daha önce kullanılan oylar silinmemiş olabilir, seçim işleminden sonra da oylar tutanağa geçirilmeden eksik ya da tamamen silinebilir. Sahtekârlık: Elektronik seçim sisteminin donanımı ve yazılımı göründüğünden farklı şekilde tasarlanabilir ya da tasarım hatalarından dolayı sistemde yaşanabilecek açıklar üçüncü şahıslar tarafından kötü niyetle kullanılabilir (Akın, 2006: 34-35).

Elektronik seçim sistemlerine yönelik çeşitli saldırılar yapılabilmektedir. Bu saldırılar dokuz kategoride suralanabilir (Norden, 2005: 25-27):

- Seçim Günü Öncesinde Makinelere Bozuk Yazılım Yüklenilmesi: Elektronik oylama makinelerine, yazılımlara ya da makineye bağlı yazıcı ve bellek kartlarına erişimi olan biri, makinenin bir şekilde arızalanmasına sebep olabilecek bozuk yazılımlar yükleyebilir.

- Kablosuz ve Diğer Uzaktan Kontrol Saldırıları: Bu saldırı, oylama makinesine doğrudan bir saldırıdır. Özellikle kablosuz bileşenlere sahip makineler bu tür saldırılara karşı savunmasız olabilmektedir.

- Oy Sayım Sunucularına Saldırlar: $\mathrm{Bu}$ saldırı, makineler oyları kaydettikten sonra gerçekleştirilmektedir. Oy sayım sunucularına doğrudan (örneğin, oyları toplayan veri tabanına) ya da dolaylı (örneğin, makinelerle sunucu arasındaki iletişime) müdahale edilebilmektedir. Her iki durumda da oylar değiştirilebilir ya da silinebilir.

- Makinelerin Yanlış Ayarlanması: Makineler yanlış ayarlanabilmektedir. Makinelere yapılan yanlış müdahale sonucunda, tüm oyların yanlış ya da doğru kullanılmasına bakılmaksızın tek bir adaya gitme durumu söz konusu olabilir. 
- Oy Verenlere Yardımcı Olmak İçin Konulmuş Olan Özelliklerin Kapatılması: Bu saldırı, makineye yönelik başka bir saldırıdır. Bu saldırıyla birlikte, oylama makinesinin bazı özellikleri devre dışı bırakılarak bazı oyların yanlış şekilde kaydedilmesine yol açılabilir.

- Hizmet Reddi Saldırıları: Bu geniş bir saldırı yelpazesini kapsamaktadır. Bu saldırı, oylama makinesinde oy vermeyi zorlaştırarak ya da imkânsız hale getirerek, seçmenlerin oy kullanmasını engelleyebilmektedir.

- Seçim Yerindeki Yolsuz Sandık Görevlileri ya da Diğer Kişiler Tarafindan Oylamayı Etkileyecek Faaliyetler: Bu tür faaliyetler arasında, oylama makinesinin yazılımında değişiklik yapılması, oylama makinesinin bazı özelliklerinin kapatılması, belli seçmenlere yanlış talimatlar verilmesi ya da oy sayım merkezlerine yanlış bilgilerin verilmesi sayılabilir.

- Oy Satın Alma Planları: Oylama makinelerine doğrudan saldırıların yapılması durumunda oyların satın alınması da mümkün olabilecektir.

- Oy Pusulalarına Saldırılar: Bu tür saldırılar, birçok noktada gerçekleştirilebilir. Oy pusulaları, oy sayma merkezine ulaşmadan saldırılara maruz kalabilir.

Elektronik seçim sistemlerinde sorun yaşayan ülkelerden örnek vermek gerekirse; Amerika da uzun yıllardır elektronik seçim sistemleri ile ilgili önemli çalışmalar yapılmasına rağmen, 2000 ve 2004 yılında gerçekleştirilen elektronik seçimlerde sahte oy kullanılmasının önüne geçilememiştir. Test için kullanılan elektronik ortam ve yazılımın, seçimlerde kullanılanlardan farklı şekilde olduğu ortaya çıkmış ve bu durum büyük tartışmalara yol açmıştır (Çetinkaya ve Çetinkaya, 2006: 131). Kaliforniya'da 2004 seçimlerinde 6692 yabancı oy olduğu tespit edilmiştir. Bunun sebebi olarak, işaret algılayan sistemlerin yeterli şekilde deneyden geçirilmemesi gösterilmiştir. Florida'da 2002 seçimlerinde bazı kongre üyeleri, sonuçlara etkisi olabilecek yazılım hatalarını tespit etmişlerdir. Virjinya'da da 2003 seçimlerinde oylama makineler durmuş ve 953 oy kullanma makinesinde modem trafiği sıkışıklığı yaşanmış ve sonuçlar ertesi güne kadar alınamamıştır. Çok sayıda seçmen, oyunu kullanamadığı düşüncesiyle itiraz etmiştir (Telciler, 2007: 240). Dolayısıyla, doğru ve güvenilir bir elektronik seçim sisteminin kurulmaması halinde önemli sorunlar yaşanabilmektedir.

\section{Elektronik Seçim Sistemlerinde Önerilen Modeller}

Elektronik seçim sistemlerinde yaşanan tartışmaların önüne geçilmesi adına, bu sistemlere kâğıt pusulalarını üretecek özellikte modeller önerilmektedir. Bu özellik ile birlikte, seçmenler gerektiğinde kullanmış oldukları oyların görebileceklerdir. Genel olarak bu sisteme uygun bir şekilde tasarlanan iki önemli model önerilmektedir. Bunlar, mercuri ve chaum modelidir.

Mercuri Modeli: Elektronik seçim sistemlerine yönelik en kapsamlı çalışma yapanların başında Rebecca Mercuri gelmektedir. Mercuri modelinin oylama sisteminde bilgisayarda kullanılan oyları içeren bir kâğıt pusulası bulunmaktadır. Bu modelde, seçmen oyunu kullandıktan sonra cam ya da ekran aracılığıyla oyunu kontrol etme şansı bulmaktadır. Seçmen, herhangi bir sebepten dolayı kullanmış olduğu oyun kâğıt pusulasında yanlış seçenekte işaretlendiğini fark etmesi durumunda, sandık görevlilerine haber verebilmekte ve sandık görevlileri de böyle bir durumda seçmenin kullanmış olduğu oyu iptal ederek, tekrar oy kullanma imkânı sağlayabilmektedir. Seçim sonuçları için bilgisayarda kullanılan oyların ön sonuçları açıklanabilir, ancak, seçimin resmî sonuçları kâğıt pusulası kayıtlarından yapılması gerekmektedir (Mercuri, 2002).

Mercuri modeli, seçmenin kullanmış olduğu oyu görebilmesi ve seçim sonuçlarına herhangi bir itiraz olması durumunda oyların tekrar elle sayılabilmesinden dolayı, elektronik seçim sistemi arayışında olan ülkeler için en önemli seçenek olarak gözükmektedir.

Chaum Modeli: Elektronik seçim sistemlerine yönelik geliştirilen diğer önemli bir model ise chaum modelidir. Bu model, mercuri modeline göre daha karmaşık bir pusula yöntemi önermektedir. Chaum modelinde, bazı şifreleme sistemi kullanılarak seçmene oyunu kullandıktan sonra yanında götüreceği bir pusula verilmektedir. 


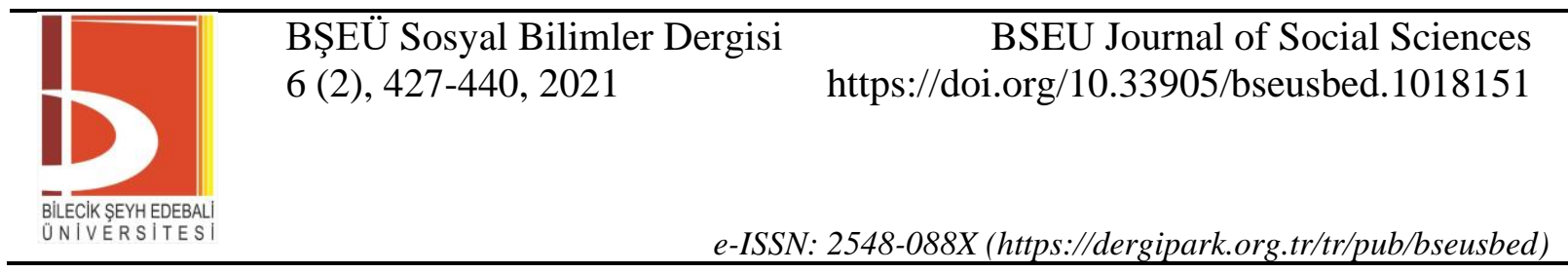

Pusulanın üstündeki bilgiler şifreli olmasından dolayı seçmenin kime oy verdiği bilinmemektedir. Ancak, her seçmen için tek üretilmektedir. Seçimden sonra makinenin kaydetmiş olduğu oylar bir wep sitesinde gösterilmekte ve seçmen gerektiğinde kullanmış olduğu oyun, bu oylar arasında olup olmadığını, kendisine verilen pusulayla karşılaştırılarak denetleyebilmektedir. Ancak, bu sistemin hem karmaşık olması hem de seçmenin denetim yapabilmesi için internet erişimine ihtiyaç duyulmasından dolayı kısa zamanda uygulanabilir görünmemektedir (Akın, 2006: 38).

\section{DÜNYADA ELEKTRONIK SEÇIM UYGULAMALARINDAN ÖRNEKLER}

Dünyada elektronik seçim uygulamasını gerçekleştiren ülke örneklerinin arasında, Brezilya, Hindistan, ABD, Venezuela, İngiltere, Kanada, Estonya, Belçika, Fransa, Avustralya, İsviçre, Norveç, İspanya ve İrlanda örnekleri verilebilir. Ancak, her ülkeyi incelemek çalışmanın sınırını aşacaktır. Bu yüzden, tüm ülke çapında elektronik seçim sistemini uygulayan Brezilya, Hindistan ve Venezuela örnekleri üzerinde durulacaktır. Bu örnekleri incelemek, Türkiye'de elektronik seçim sisteminin uygulanabilirliğini değerlendirmek açısından son derece önemlidir.

\section{A. Brezilya}

Brezilya'da elektronik seçim makineleri 1995 yılında geliştirildi ve ilk olarak 1996 yılında belediye seçimlerinde kullanıldı. Brezilya'daki bu makineler, seçmen tanımlama, oy verme ve oyları toplama için kullanılmaktadır. Siyasi partiler, denetim için bu makinelere erişebilmektedirler. Oylama sistemi, oy sayısını büyük ölçüde hızlandırdığı için dolandırıcılığın önüne geçilmekte ve bundan dolayı bu elektronik makineler yaygın olarak kabul görmektedir. Başlangıçta, bu elektronik makine sistemlerine bir kâğıt izi eklenmiştir. Daha sonra yazıcılarla ilgili teknik sorunlar çıkmasından dolayı kâğıt izinden vazgeçilmiştir. Oy denetiminin imkânsız olduğu düşünüldüğünden, kâğıt izinin eksik olması bazen eleştiri almaktadır (ACE, 2016). Aşağıdaki şekilde de Brezilya'da kullanılan elektronik oy makinesi gösterilmiştir.

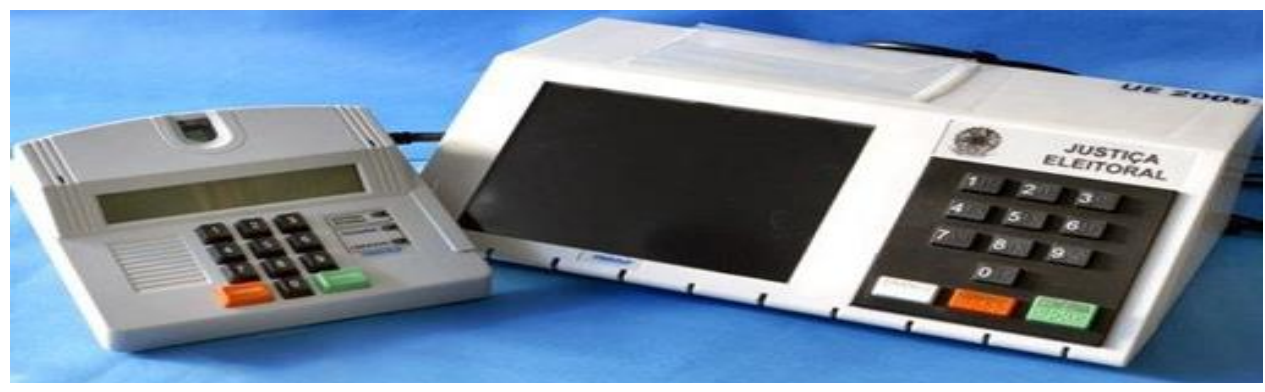

Şekil 2. Brezilya'da kullanılan oy verme makinesi

Brezilya Yüksek Seçim Mahkemesi, bu makinelerin güvenliğini artırmaya yönelik araştırmaları düzenli olarak finanse etmektedir. Örneğin, 2009'da teknolojiye ek güven sağlamak için bir bilgisayar korsanlığg yarışması düzenlendi. 2011 yılında ise yeni biyometrik tabanlı seçim makineleri geliştirildi. Yüksek Seçim Mahkemesi, 2012 yılında da seçim sürecinde biyometrik tanımlama uygulamasını başlatmıştır (ACE, 2016). Biyometrik tanımlama sistemi, seçmenlerin kimliğini teyit etmekte ve böylece seçimlerin güvenilir bir şekilde yapılmasını sağlamaktadır.

Brezilya Yüksek Seçim Mahkemesi, 2014 genel seçimleri için 2013 yılında Biyometrik Kimlik Seçmen programının üçüncü aşamasını da hayata geçirmek için çalışmalar başlatmıştır. Brezilya'da 2014 yılında yapılan seçimlerde, 16 milyon seçmen göz önüne alınarak tüm federal bölgelerden ve eyaletlerden 23.7 milyon seçmenin biyometrik tespiti yapılmıştır. Bu sistemin birçok avantajı olmasının yanı sıra, Brezilya seçmenleri için başka amaçlara da hizmet edebilecek şekilde tasarlanmıştır. Aşamalı olarak hayata geçirilmeye çalışılan bu çalışmaların hem Brezilya nüfusu hem de seçmen sayısı göz önüne alındığında daha çok mesafe kat edilmesi gerektiğini de ortaya koymaktadır (Aydın, 2015: 145). 


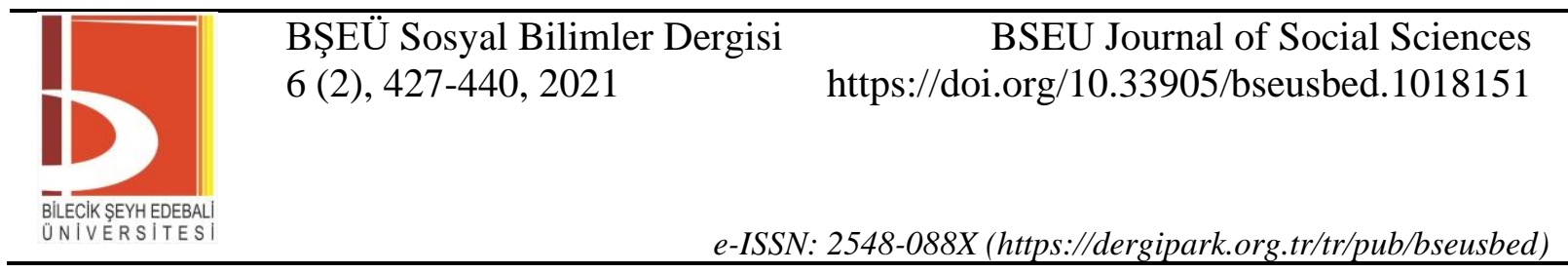

\section{B. Hindistan}

Hindistan genel seçimlerinde Electronic Voting Machines (EVM) sistemi kullanılmaktadır. Hindistan'daki EVM' ler 1990 yılından itibaren önce deneme amaçlı kullanıldı ve 1998 seçimlerinden itibaren de genel seçimlerde kullanılmaya başlandı. EVM' ler oy pusulası birimi ve denetim birimi olmak üzere iki birimden oluşmaktadır. Bu iki birim 5 metrelik bir kabloyla birbirine bağlıdırlar. Oy pusula birimi seçmenin oy kullandığı sandık odasındadır, denetim birimi ise seçim sandık görevlisinin yanındadır (Telciler, 2007: 241-242). EVM sistemi ile birlikte, kâğıt pusulası kullanılarak yapılan seçimlerde ortaya çıkan hilelerin önüne geçilmesi amaçlanmaktadır. Aşağıdaki şekilde de Hindistan seçimlerinde kullanılan EVM sistemi gösterilmiştir.

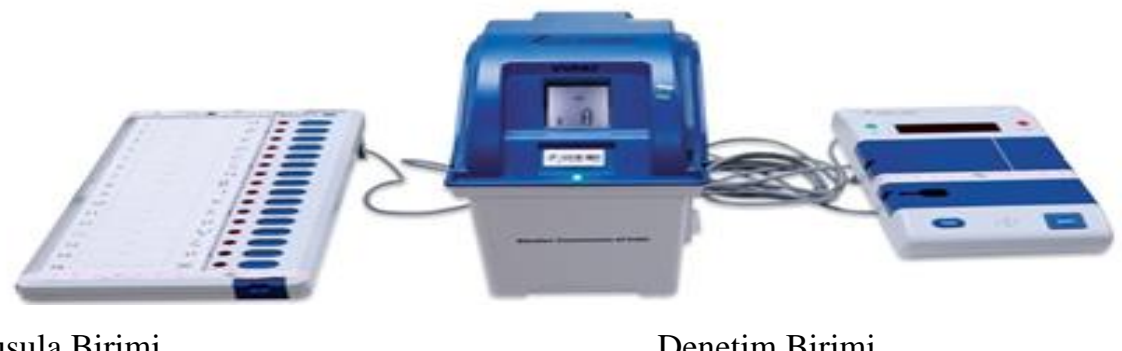

Oy Pusula Birimi

Denetim Birimi

Şekil 3. Hindistan'da oy verme makinesi

EVM sistemde oy verme işlemi şu şekilde özetlenebilir (Telciler, 2007: 241): Seçim başlamadan önce seçim görevlisi, sonuç düğmesine basarak daha önce kullanılmış ya da hileli oyların olup olmadığını gösterir. Seçim görevlisi, diğer görevlilere de deneme amacıyla oy kullanmalarını söyler ve sonuç düğmesine basılarak oy verme işleminin gerçek sonuçları verdiğini gösterir. Daha sonra "temizle" tuşuna basılarak daha önce yapılan bütün sonuçlar iptal edilir ve gerçek oy verme işlemi başlatılır. Seçmen, oylama makinesinde partisini ya da adayını seçip işaretledikten sonra "mavi düğmeye" bastı̆̆ anda kırmızı ışık yanmaya başlar ve bip sesi gelir. Bu ses seçmenin kullanmış olduğu oyun kayda geçtiği anlamına gelir. Son seçmen de oyunu kullandıktan sonra, sandık sorumlusu "kapat" düğmesine basar. Bu işlemden sonra artık EVM' ler hiçbir oyu kabul etmeyecektir. Daha sonra, oy pusula birimi, denetim biriminden ayrılarak güvenliğe alınır. Gerekli önlemler alındıktan sonra, seçim birimi başkanı ile diğer görevliler birlikte sayım işlemine başlar. Herhangi bir çelişki olması durumunda oy pusula birimleri gözden geçirilir.

Hindistan'da ilk zamanlarda EVM' lerde ayrı bir kâğıt pusula üretilmemesi oylamanın doğrulunu denetlenmesinin önüne geçmekteydi ve bu durum büyük eleştirilere yol açmaktaydı. Hem eleştirilerinin önüne geçmek hem de siyasi baskılardan kurtulmak adına, 2014 yılında bir kâğıt denetim izi getirilmesine karar verilmiştir.

\section{Venezuela}

Venezuela, tüm seçimlerde elektronik oy kullanan yalnızca dört ülkeden biridir (diğerleri Hindistan, Brezilya ve Butan'dır). Elektronik oylama, Venezuela'da ağır şekilde denetlenen bir süreçtir (NDI, t.y.). Venezuela seçimlerinde kullanılan elektronik oylama işlemi, Smartmatic Auditable Elections Systems (SAES) adı verilen makinelerle gerçekleştirilmektedir. SAES sistemi tamamen denetlenebilir bir özellikte olduğu için diğer oylama makinelerinden ayrı bir öneme sahiptir. Aşağıdaki şekilde de bu sistemin şekli gösterilmiştir. 


\begin{tabular}{|c|c|c|}
\hline & $\begin{array}{l}\text { BŞEÜ Sosyal Bilimler Dergisi } \\
6(2), 427-440,2021\end{array}$ & $\begin{array}{r}\text { BSEU Journal of Social Sciences } \\
\text { https://doi.org/10.33905/bseusbed.1018151 }\end{array}$ \\
\hline 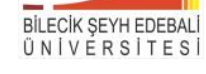 & $e-I S S \Lambda$ & 2548-088X (https://dergipark.org.tr/tr/pub/bseusbed) \\
\hline
\end{tabular}

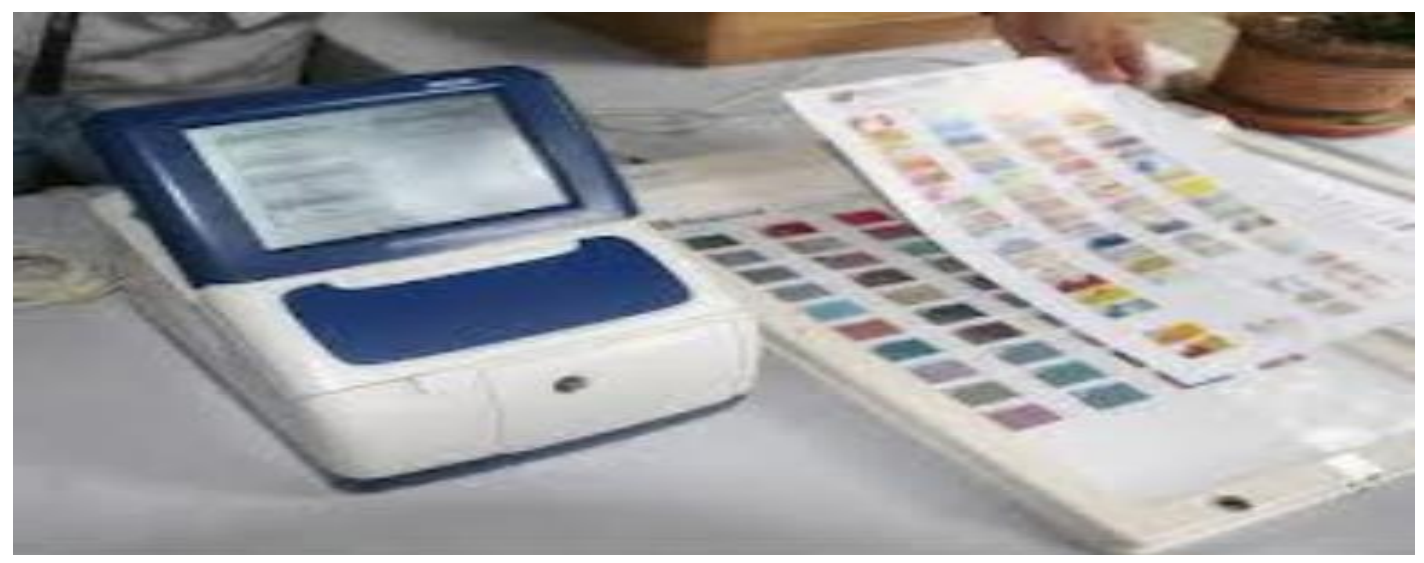

Şekil 4. Venezuela'da oy verme makinesi

Venezuela'da seçmen, oyunu kullanmak üzere oylama makinesinin başına gelir ve parmak izini makineye doğrulattıktan sonra, direkt oy kullanılabilmesi için makine aktif hale getirilir. Daha sonra seçmen, partiler ya da adaylar arasında seçimini gerçekleştirir. Seçmenin tercihi ekrana gelir ve seçmen oy seçeneği tuşuna basmasıyla oyunu onaylama imkânına sahip olur. Seçmenlerin kullandığı oylar rastgele sistemde depolanır ve sonrasında toplam kayıtların çıktısına yansıtılır. Seçmenlerin kullanmış oldukları oylar, geri denetimde makbuz kutusunun fiziki kanıtına karşı kontrol edilebilmektedir (Aydın, 2015: 141). Seçmenlerin birden fazla oy kullanmasını engellemek adına alınan parmak izi, ulusal veri tabanındaki parmak izleriyle karşılaştırılabilmektedir. Böylece seçimlerin güvenilir bir şekilde gerçekleştirilmesi noktasında, önemli başarılar elde edilebilmektedir.

\section{TÜRKIYY'DE ELEKTRONIK SEÇIMM SISTEMINIIN UYGULANABIILİRLIĞí}

Türkiye'de 22 Temmuz 2007 seçimlerinden beri uygulanmakta olan Seçim Bilişim Sistemi (SEÇSİS) projesi, bilinen ilk elektronik seçim sistemi çalışmasıdır. Yüksek Seçim Kurulu tarafından uygulanmakta olan SEÇSİS projesi, seçime yönelik her türlü işlemlerin yürütüldüğü bir elektronik sistemdir. SEÇSİS projesi ile ilgili yapılan ilk çalışmaların 1986 yılına kadar uzanması, Türkiye'nin teknoloji konusunda elektronik seçim sistemine çok ta uzak olmadığının bir göstergesidir. Bu proje, teknolojinin daha da gelişmesiyle birlikte, günümüzün şartlarına göre tasarlanmış ve bugünkü halini almıştır.

Seçim ile ilgili bilgi ve işlemlerin elektronik ortamda hızlı ve kolay bir şekilde yürütülmesini sağlayan SEÇSİS projesi, bir elektronik seçim sistemi değildir. Bu proje, elektronik seçim yönetimi ve bilgi portalı olarak çalışmaktadır. Ancak, bu proje, Türkiye'de elektronik seçim sistemine geçiş aşamasına ön ayak oluşturmasından dolayı oldukça önem arz etmektedir.

Türkiye'de elektronik seçim sistemi ile ilgili önemli çalışmalar yapılmasına rağmen, bu sistemin Türkiye'de uygulanması halinde ciddi bir kesim tarafından olumsuz karşılanacağı ve büyük tartışmalara sebep olacağ1 düşünülmektedir. Bunun en büyük sebepleri arasında teknoloji ve teknoloji okuryazarlığı seviyesinin Türkiye'de düşük olması gösterilebilir. Ancak, dünyada ilk elektronik seçim sistemini uygulayan ülkelerden biri olan Hindistan'da halkın bilgisayar okuryazarlığı seviyesinin Türkiye'ye göre daha düşük olmasına rağmen, bu sistemin seçimlerde başarıyla uygulanması Türkiye için ümit vericidir. Bilindiği üzere, Türkiye'de 15-50 yaş arasında olan bireyler, çoğunlukla işlerini internet üzerinde yapabilmektedir. 50 yaş üzerinde olan bireylerin ise işlemlerini genellikle klasik yöntemler ile gerçekleştirdiği, teknolojiyi kullanmak istemedikleri ve hatta teknoloji mağduru olma ihtimalleri gibi düşüncelerinin olduğu bilinmektedir. Bu düşünceye sahip bireylerin her yaşta olacağ1 düşünüldüğünde, Türkiye'de uygulanabilecek bir elektronik seçim sisteminin, güvenilir olması, kolay ve anlaşılır olması, seçmende hiç endişe uyandırmaması, klasik yöntemlere göre daha fazla iş yükü olmaması ve denetlenebilir olması gerekmektedir (Erzurumlu ve Koloğlu, 2017: 4). 
Türkiye'de uygulanabilecek elektronik seçim sisteminin, daha önce (çalışmanın A. Elektronik Seçim Sistemi İ̧̧in Kriterler başlığında) belirtilen kriterlerin yanı sıra, ülkenin koşulları göz önünde tutularak şu özelliklere sahip olması gerekmektedir (Akın, 2006: 43-44):

- Kullanım Kolaylığı: Elektronik seçim sistemine geçilebilmesi için öncelikle bu sistemin hem görünüş hem de kullanılış açısından alışılan klasik oy pusulasına benzer şekilde tasarlanması gerekmektedir. Bu sistem, seçim günü kolayca kurulup kaldırabilir özellikte olmalı ve seçim işlemi başlamadan önce de test edilebilmelidir. Yeni sistemde kullanılacak oylama makineleri, birden fazla seçimde kullanılacağı için kolayca depolanabilmeli ve taşınabilmelidir.

- Sürekli Çalışma: Elektronik seçim sisteminde kullanılacak olan oylama makineleri, seçim gününde oy verme işleminin başlangıç ve bitiş saatine kadar sorunsuz bir şekilde çalışabilmelidir. Elektrik kesintisi olması halinde bile bu makineler, çalışmaya devam edebilmeli ve kullanılan oylar hafızada tutulabilmelidir.

- Kâğlt Pusula Üretimi: Elektronik seçim sisteminde kullanılacak oy makineleri, bir kâğıt oy pusulası üretebilmeli ve seçmenin onayından sonra bu pusulalar el değmeden seçim sandığında arşivlenmelidir. Herhangi bir itiraz olması halinde kâğıt oy pusulaları kullanılabilecektir.

- Ă̆ Bağlantıst: Elektronik oylama makinelerinin ağ bağlantısı olmamalıdır. Böylece dışarıdan yapılabilecek müdahaleler sonucu seçimin sabote edilmesi ya da oylarının değiştirilmesinin önüne geçilebilir.

- Güvenlik: Elektronik oy verme makineleri, dışarıdan fiziksel ya da elektronik müdahaleye imkân vermemeli ve oy verme işlemi dışarıdan takip edilmemelidir. Her makine özel bir anahtarla açılmalı ve bu anahtarlar seçim kurullarında olmalıdır. Bu oylama makinelerinin birden fazla seçimde kullanılmaları amaçlandığı için güvenli bir şekilde depolanmaları için özel yerler hazırlanmalıdır.

- Açık Kod: Oy verme makinelerinde kullanılacak olan yazılımların kaynak kodları seçmenlerin denetimine açık olmalıdır.

- Makine Standardl: Oy verme makinelerinin özellikleri, Türk Standardları Enstitüsü’nün bir standardı ile belirlenmeli ve bu standarda uygunluk iddiasında bulunan makinelerin testleri için Yüksek Seçim Kurulu'nun denetiminde olan teknik bir birim kurulmalıdır.

Türkiye'de uygulanabilecek elektronik seçim modeli olarak ise Hava Elektronik Sanayi (HAVELSAN) tarafından tasarlanan elektronik seçim sandığg (e-sandık) gösterilebilir. Yukarıda sayılan özelliklerin çoğunu karşılayan elektronik seçim sandığı projesi ilk defa Türkiye Bilişim Derneği’nin 30. Olağan Genel Kurulunda kullanıldı ve oldukça başarılı bulundu.

12. Uluslararası Savunma Sanayi Fuarında elektronik seçim sandığını tanıtan HAVELSAN Seçim Sistemleri Proje Yöneticisi İsmail Göktaş, bu projeye 2010 yılında başlandığını ve 2013 yılında tamamlandığını ifade etmiştir. Elektronik sandık projesinin amacı, seçmenlerin elektronik ortamda oy vermesini sağlamaktır. Göktaş'ın verdiği bilgiye göre, oy pusulası, dijital bilgi kullanılarak hazırlanmakta ve normal bir oy pusulasından hiçbir farkı bulunmamaktadır. Bu dijital bilgilerde seçmen ve sandık bilgileri içermektedir. Bu proje ile birlikte hem geçersiz oyların engelleneceği hem de 5-10 dakika içinde Türkiye genelindeki tüm sandıkların sayılabileceği belirtilmektedir (Memurlar.net, 2015).

Elektronik sandık projesinin oldukça güvenilir olduğu iddia edilmekte ve seçim süresince oylama makinesi çalışırken herhangi bir ağ bağlantısı bulunmayacağı öne sürülmektedir. Bu proje ile birlikte, oylarla ilgili yapılan itirazlar, çöplerden çıkan oylar ya da seçim sonuçlarının haftalar sonra açıklanması durumunun sona ereceği ifade edilmektedir. Yeni seçim sistemiyle hem zamandan ve paradan tasarruf yapılacağı hem de harcamaların büyük oranda düşeceği belirtilmektedir. Bu sistemle birlikte, yurt dışı oyların Türkiye'ye uçakla taşınmasına da gerek duyulmayacağı öne sürülmektedir. Elektronik seçim sandık projesinin kullanımı da oldukça kolay görünmektedir. Seçmenler, öncelikle makineyi kullanabilmek için kimliklerini gösterecek ve sandık kurulundan rastgele tanımlı olan karekod fişlerini alacaktır. Ardından almış oldukları karekodu makineye tuttuktan 
sonra "oylamayı başlat” sekmesine tıklayarak, istediği partiye oyunu verebilecektir. Seçmenler, oy verme işlemini tamamladıktan sonra makineden alacakları pusulayı, bu kez gerçek sandıklara atacaklardır (Memurlar.net, 2015). Böylece seçim sonuçlarına itiraz olması durumunda, sandıklara atılan oy pusulaları sayılabilecek ve bu oy pusulaları elektronik makinelerde kullanılan oylarla karşılaştırabilecektir.

Türkiye'de elektronik seçim sisteminin uygulanması halinde büyük bir kesim tarafından tepkiyle karşılanması ve büyük tartışmalara sebep olması beklenmektedir. Ancak, teknolojinin geliştiği bu dönemde birçok ülkede olduğu gibi, Türkiye'de de elektronik seçim sistemi uygulanabilir. Bilindiği üzere, son yıllarda Türkiye'de teknoloji alanında önemli çalışmalar gerçekleştirilmekte ve bu çalışmaların sayısı gün geçtikçe de artmaktadır. Dolayısıyla değişen ve gelişen bir teknolojik dönemde, doğru, güvenilir ve denetlenebilir bir elektronik seçim sisteminin, Türkiye'de uygulanması mümkün görünmektedir. Türkiye'de elektronik seçim sisteminin uygulanması halinde ilk seçenek olarak da HAVELSAN tarafından geliştirilen elektronik seçim sandığ 1 uygulamasının tercih edilebileceği söylenebilir.

\section{SONUÇ}

Son yıllarda başta bilişim sistemleri alanı olmak üzere, birçok alanda önemli bir değişim ve dönüşüm süreci yaşanmaktadır. Bu değişim ve dönüşüm süreciyle birlikte, birçok hizmet elektronik ortamda verilmekte ve bu hizmetlerin sayısı gün geçtikçe de artmaktadır. Özellikle, yazılım ve donanım alanındaki ilerlemelerle birlikte, elektronik seçim çalışmalarının da olumlu etkileneceği düşünülmekte ve bu alanda yaşanan gelişmelerin etkisiyle, daha hızlı ve daha güvenli oy kullanılacağı öne sürülmektedir.

Elektronik seçim sistemlerine yönelik yapılan çalışmaların sayısı gün geçtikçe artmaktadır. Bu seçim sistemi, bir yandan desteklenirken, diğer yandan da büyük tartışmalara yol açabilmektedir. Ancak, bu sistemin, özellikle Brezilya ve Hindistan gibi kalabalık ülkelerde başarılı bir şekilde uygulanması, başta Türkiye olmak üzere birçok ülkeye örnek teşkil etmektedir.

Türkiye'de elektronik seçim sisteminin uygulanabilmesi için, çalışmada belirtilen teknik sorunlar, hatalı kullanım ve sahtekârlık gibi temel sorunlara çözüm bulunmalı ve iyi bir planlama yapılmalıdır. Yüksek Seçim Kurulu öncülüğünde yapılacak bir elektronik seçim sistemi hem seçimlerde maliyetlerin azaltılması hem de hızlı sonuç alınması açısından son derece önem arz etmektedir. Bu seçim sisteminde birçok şekilde ve farklı alanlarda sorunlar yaşanabilir, ancak, seçimlerin bir ülkenin kaderini belirleyebilecek kadar önemli olması sebebiyle yapılacak seçim için her türlü tedbirin alınması ve gerekli düzenlemelerin yapılması gerekmektedir.

Türkiye'de uygulanabilecek elektronik seçim modeli olarak, HAVELSAN tarafından tasarlanan elektronik seçim sandığı uygulaması tercih edilebilir. Elektronik seçim sandığı uygulamasının, dünyada tercih edilen elektronik oylama makineleri ile yakın standartta olduğu görülmektedir. Kullanımı oldukça kolay görülen elektronik seçim sandığ1, herhangi bir ağ içinde olmadığı için uzaktan erişim yoluyla oylar üzerinde değiş̧iklik yapılması zor görünmektedir. Ayrıca, bu uygulamada oy verme işlemi tamamlandıktan sonra, makineden alınacak olan pusula sandıklara atılmakta ve elektronik ortamda yapılan sayımlara itiraz olunması halinde sandıklar açılarak oylar karşılaştırılabilmektedir. Elektronik seçim sandığı uygulamasının doğru ve güvenilir bir şekilde uygulanması halinde seçim sonuçları hızlı bir şekilde elde edilebilecektir.

Türkiye'de elektronik seçim sisteminin uygulanması halinde, bu uygulamanın önemli bir kesim tarafından olumsuz karşılanacağı beklenmektedir. Ancak, gelişen teknoloji ile birlikte yasal ve yapısal bir dönüşümle seçim güvenliği sağlanarak, bu uygulamaya olan güven artırılabilir. Dolayısıyla elektronik seçim sistemi uygulamasına yönelik iyi bir planlama yapılması, halkın eğitim ve bilinç düzeyinin artırılması halinde, bu uygulama ilerleyen süreçte, toplumun bir büyük kesimi tarafından kabul ve destek görebilecektir. Bu seçim sistemi, ilk olarak pilot bölgelerde gerçekleştirilecek, ardından da ülke genelinde uygulanmasına geçilebilecektir. 


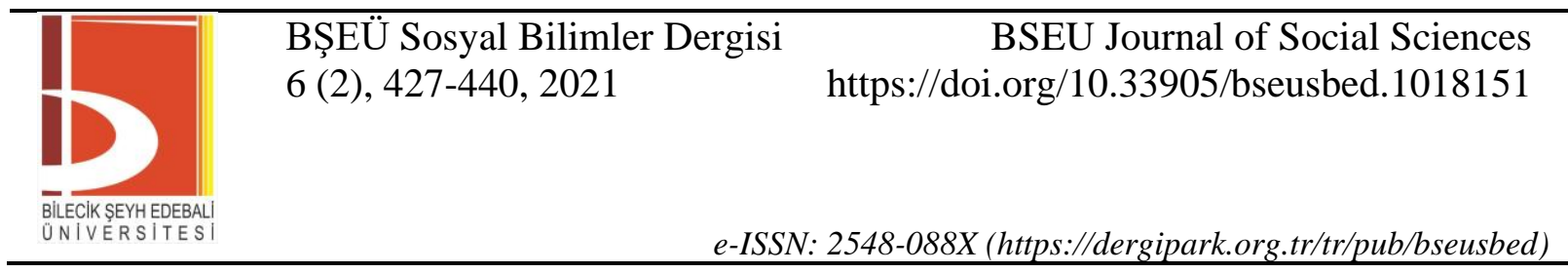

\section{KAYNAKLAR}

ACE (2016). E-voting. [Erişim:16.09.21, http://aceproject.org/ace-en/focus/e-voting/countries]

Akın, M. (2006). Elektronik Oy Verme Sistemlerinde Güvenlik: Deneyimler ve Türkiye İçin Öneriler. İstanbul Üniversitesi İktisat Fakültesi Ekonometri ve İstatistik Dergisi, 3, 32-47.

Aydın, N. (2015). Dünya'da ve Türkiye'de Seçimlerin Yönetimi ve Denetimi. Ekin Yayınevi.

Barlow, L. (2003). An Introduction ro Electronic Voting. 1-13. [Erişisi:12.09.2021, http://citeseerx.ist.psu.edu/viewdoc/download?doi=10.1.1.136.2993\&rep=rep1\&type=pdf]

Buchsbaum, T. M. (2004). E-voting: International Developments and Lessons Learnt, 31-42. [Erişim: 10.09.2021, https://subs.emis.de/LNI/Proceedings/Proceedings47/Proceeding.GI.47-4.pdf]

Çetinkaya, D., \& Çetinkaya, O. (2006). E-Seçim Uygulamaları İçin Gereksinimler ve Tasarım İlkeleri. XI. "Türkiye'de Internet" Konferansı Bildirileri içinde (123-133). TOBB Ekonomi ve Teknoloji Üniversitesi.

Erzurumlu, K., \& Koloğlu, T. F. (2017). Türkiye'de E-Seçim Sisteminin Uygulanabilirliğiyle İlgili Çalışma ve Uygulama Geliştirme. 19. Akademik Bilişim Konferansı Bildiriler Kitabı içinde (1-7). Aksaray Üniversitesi Yayını.

Güleş, H. K., \& Özata, M. (2005). Sağllk Bilişim Sistemleri. Nobel Yayınları.

Gümüştekin, G. E. (2004). İşletmelerde Yönetim Bilişim Sistemleri. Celal Bayar Üniversitesi Yönetim ve Ekonomi Dergisi, 11 (1), 125-141.

Internet Policy Institute (2001). Report of the National Workshop on Internet Voting: Issues and Research Agenda. Sponsored by the National Science Foundation, 1-62.

Memurlar.net (2015). E-Sandık Sistemi 5-10 Dakikada Tüm Sandıkları Saylyor!. [Erişim: 20.09.2021, https://www.memurlar.net/haber/513362/e-sandik-sistemi-5-10-dakikada-tum-sandiklari-sayiyor.html]

Mercuri, R. (2002). A Better Ballot Box. [Erişim: 15.9.2021, https://spectrum.ieee.org/computing/software/a-better-ballot-box]

NDI (2013). Electronic Voting and Counting Around the World. [Erişim:11.09.2021, https://www.ndi.org/e-voting-guide/electronic-voting-and-counting-around-the-world]

NDI (t.y). E-Voting Audits in Venezuela. [Erişim:17.09.2021, https://www.ndi.org/e-votingguide/examples/e-voting-audits-venezuela]

Norden, L. (2006). The Machinery of Democracy: Protecting Elections in an Electronic World, rapor. Voting Rights \& Elections Series, Brennan Center for Justice at NYU School of Law.

Özgen, H., \& Yalçın, A. (1992). İşletmelerde «Yönetim Bilişim Sistemi» ve Yönetim Kararlarında Kullanılması. Eskişsehir Anadolu Üniversitesi İktisadi ve İdari Bilimler Fakültesi Dergisi, X (1-2), 249-264.

Telciler, C. (2007) Elektronik Seçim Sistemi. Akademik Bilişim'07 - IX. Akademik Bilişim Konferansı Bildirileri içinde (237-246.) Kütahya: Dumlupınar Üniversitesi.

Yozgat, U. (1998). Yönetim Bilişim Sistemleri. Beta Yayınları. 